Opinion

Volume 1 Issue 1 - August 2015
Int J Environ Sci Nat Res

Copyright $₫$ All rights are reserved by Frederik De Pesseroey

\title{
Towards Modeling of Waste Collection Systems
}

\author{
Frederik De Pesseroey* \\ Addvice, Belgium
}

Submission: September 14, 2015; Published: September 16, 2015

*Corresponding author: Frederik, Beekstraat, 529120 Vrasene, Belgium, Tel. no: 0032485975659, Email: frederik@addvice.be

\section{Introduction}

Last decade, the differentiation in types of waste collection systems for household waste is expanding strongly. We see a shift from people service (door-to-door collection) to selfservice (bring-your-waste systems). Every system has his own advantages and disadvantages.Governments has to start modelling the service level of their waste collection systems, based on 'the pace of production' and 'the need to quick disposal'. If they allow more for customer perspectives, managing of waste behaviour will be easier and cheaper. If they don't start modelling, they'll only have the highest service for the resource streams with the highest economic value. Did you know that the speed of innovation is linked to the total number of people living on the planet. If you look at history, the world population explosion is a recent phenomenon. Today, we are halfway the S-curve. The pace of innovation still accelerates, either in waste collection systems.

It's not obvious that, in the 21th century, we still collect our waste as in the 19th century. Migration to the cities still continues. We are going to live with more people on the same space. The demand for housing rises. Private living area decreases. We have less space to manage waste at home. A spectrum of innovations in bring-your-waste systems emerge. Ten years ago, the main driver for companies to start with "self-service policy" solutions were efficiency (e.g. cost reduction). Today's consumers see selfservice as the perfect solution for their demands. Also in waste collection systems, we see this shift from people service (door-todoor collection) to self-service (bring-your-waste systems). Some examples.

\section{Bring-your-waste systems}

1. Waste collection machines for waste fractions (with high economic value) at the entrance of large department stores, where consumers can get a coupon to exchange in the department store.

2. Mobile waste reception centers: a collection truck or container, which can collect several waste fractions, is drawn up at a certain place and on a predetermined date.

3. Collection system for organic kitchen waste with dry grinders. The organic waste is collected in a separate storage tank under the kitchen sink.
4. Collection points for single waste streams: textiles, small WEE cooking oil, household battery drop off points, ...

5. Systems, in which the waste is transported underground (with a strong air flow) to a receiving terminal (by pipes and tubes) with access points in public or private space.

6. (Underground) container systems, at the corner of the street, for various waste fractions and access card controlled.

7. Large waste reception centers for demolition and bulky waste at the borders of thecities.

In additionthe these large variation in waste reception centers, we seetherise of bring-your-waste systems out of home/on the go. "Reverse vending machines" for example: vending machines for the collection of waste, comparable with the vending machines for drinks and sweets. They make the link between consumption and waste production. Or in some cities, you can pay for your subway ride by recycling a plastic bottle. Even ifyou want toreuse/reduceyour waste, youcanbringyour 'resources': reuse events, where people can sell and buy used clothes; "Community fridges" for food waste prevention, ...

\section{Door-to-door collection}

In door-to-door collection, we seelessinnovations, but they are stillinspiringforthinlypopulatedareas: several waste

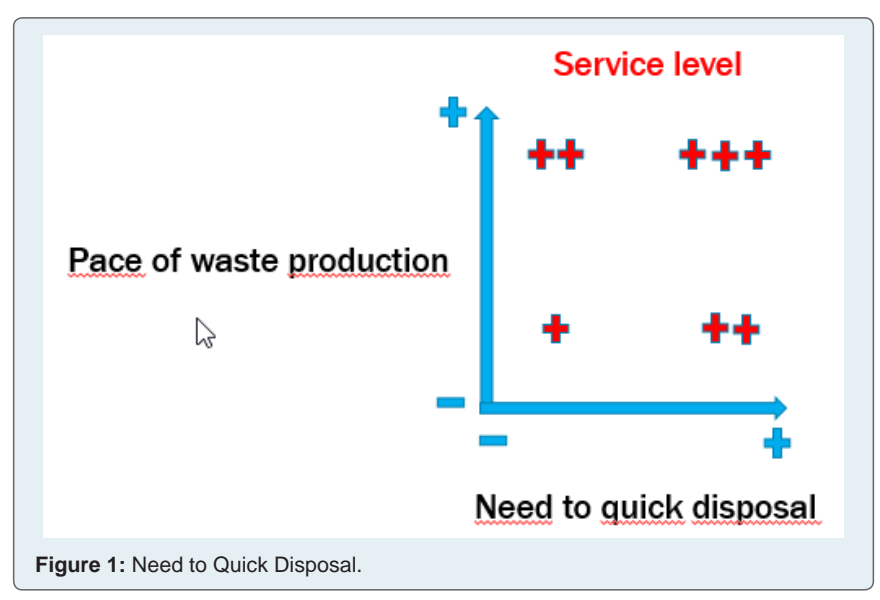


fraction (residual/plastics/organics/metal/...) in a single bag or bin; sorted at the processors. This means thatonlyone waste collection truck is requiredforthevariouswaste streams. Somecities are experimentingwith different service levels of door-to-door collection, depending on thefact of the waste fraction is recyclable. They have a low service level for residual waste and a high service level for recyclable waste.

\section{Towards modeling of waste collection systems}

The differentiation in types of waste collection systems is expanding strongly. The systems are more customers centric, especially the self service solutions (You can bring your waste when it suits you. You don't have to store your waste and wait for collection day.) Governments have to start modelling their waste collection systems, based on customer's perspectives. Why? There is no/ a limited competition in this market. If governments allow more for customer perspectives, managing of waste behaviour will be easier and cheaper.
How can we do that? Position your waste fraction in a matrix of 2 dimensions (see below) and make sure that waste fractions with a high pace of production and a great need to quick disposal (e.g. organics) have a collection method with a high service level. Waste fractions with a low pace of production and an small need to quick disposal (e.g. textile) can have a (cheaper) collection method with a lower service level. (Bulky and demolition waste has a low pace of production and a great need to quick disposal, packaging waste has a high pace of production but the need of quick disposal is lower than residual waste,) (Figure 1).

\section{Conclusion}

If governments start modelling their waste collection systems, based on customer perspectives, managing of waste behaviour will be easier and cheaper. If they don't start modelling, they 'll only have the highest service for resource streams with the highest economic value. 